November 7, 2011

Mr. John Hickman

U.S. Nuclear Regulatory Commission

Materials Decommissioning Branch

Division of Waste Management and Environmental Protection

Mail Stop T8F5

Rockville, MD 20852

\title{
SUBJECT: INDEPENDENT CONFIRMATORY SURVEY REPORT FOR THE UNIVERSITY OF ARIZONA NUCLEAR REACTOR LABORATORY, TUCSON, ARIZONA \\ DCN: 2051-SR-01-0
}

Dear Mr. Hickman:

The Oak Ridge Institute for Science and Education (ORISE) is pleased to provide the enclosed report that details the confirmatory survey activities that were performed during the week of September 6, 2011, at the University of Arizona Nuclear Reactor Laboratory. The survey activities were conducted in accordance with an ORISE confirmatory survey plan provided to and approved by the U.S. Nuclear Regulatory Commission (NRC). Comments on the draft report have been addressed in this final version of the report.

Please contact me at 865.574 .6273 or Erika Bailey at 865.576 .6659 should you have any questions.

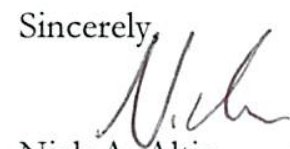

Nick A. Altic

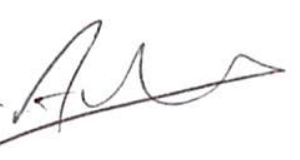

Health Physicist/Assistant Project Manager

Independent Environmental

Assessment and Verification

NAA:bj

Enclosure

c: R. Evans, NRC

B. Watson, NRC

electronic distribution:
S. Roberts, ORISE

E. Bailey, ORISE
S. Giebel, NRC

File/2051

T. Vitkus, ORISE 


\section{FINAL- INDEPENDENT CONFIRMATORY SURVEY REPORT FOR THE UNIVERSITY OF ARIZONA NUCLEAR REACTOR LABORATORY TUCSON, ARIZONA}

Nick Altic

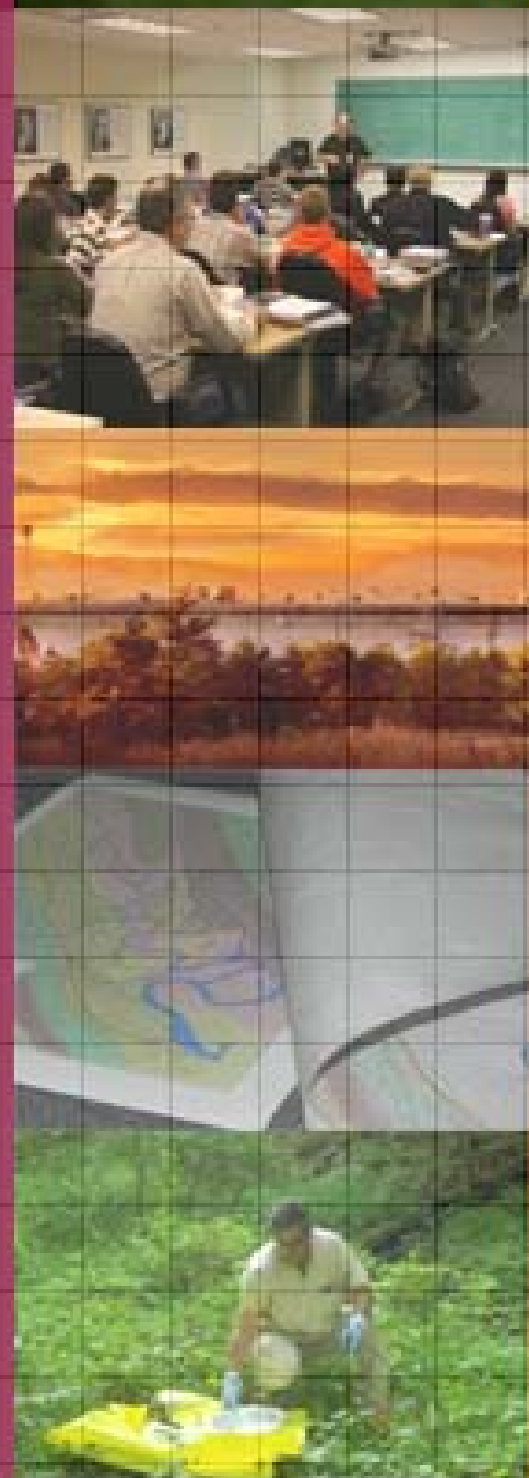

Prepared for the

U.S. Nuclear Regulatory Commission

\section{O R I S E}

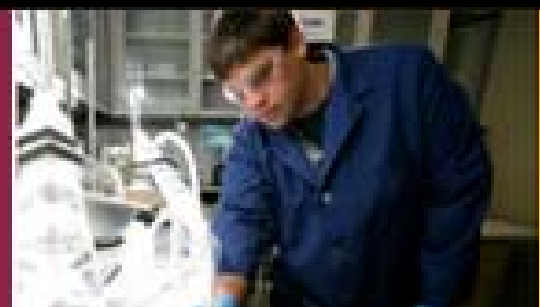

Approved for public release; further dissemination unlimited. 
The Oak Ridge Institute for Science and Education (ORISE) is a U.S. Department of Energy institute focusing on scientific initiatives to research health risks from occupational hazards, assess environmental cleanup, respond to radiation medical emergencies, support national security and emergency preparedness, and educate the next generation of scientists. ORISE is managed by Oak Ridge Associated Universities.

\section{NOTICES}

The opinions expressed herein do not necessarily reflect the opinions of the sponsoring institutions of Oak Ridge Associated Universities.

This report was prepared as an account of work sponsored by the United States Government. Neither the United States Government nor the U.S. Department of Energy, nor any of their employees, makes any warranty, expressed or implied, or assumes any legal liability or responsibility for the accuracy, completeness, or usefulness of any information, apparatus, product, or process disclosed, or represents that its use would not infringe on privately owned rights. Reference herein to any specific commercial product, process, or service by trade name, mark, manufacturer, or otherwise, does not necessarily constitute or imply its endorsement or recommendation, or favor by the U.S. Government or any agency thereof. The views and opinions of authors expressed herein do not necessarily state or reflect those of the U.S. Government or any agency thereof. 


\title{
FINAL - INDEPENDENT CONFIRMATORY SURVEY REPORT FOR THE UNIVERSITY OF ARIZONA NUCLEAR REACTOR LABORATORY TUCSON, ARIZONA
}

\author{
Prepared by \\ N. A. Altic

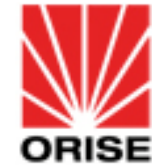 \\ Independent Environmental Assessment and Verification Program \\ Oak Ridge Institute for Science and Education \\ Oak Ridge, Tennessee 37831-0017 \\ Prepared for the \\ U.S. Nuclear Regulatory Commission
}

FINAL REPORT

NOVEMBER 2011

Prepared by the Oak Ridge Institute for Science and Education, under interagency agreement (NRC FIN No. F1008) between the U.S. Nuclear Regulatory Commission and the U.S. Department of Energy. The Oak Ridge Institute for Science and Education performs complementary work under contract number DE-AC05-06OR23100 with the U.S. Department of Energy. 
FINAL - INDEPENDENT CONFIRMATORY SURVEY REPORT FOR THE UNIVERSITY OF ARIZONA

NUCLEAR REACTOR LABORATORY TUCSON, ARIZONA

Prepared by:

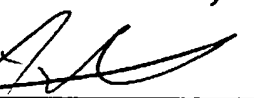

Date:

N. A. Altic, Assistant Project Manager

Independent Environmental Assessment and Verification

Reviewed by:

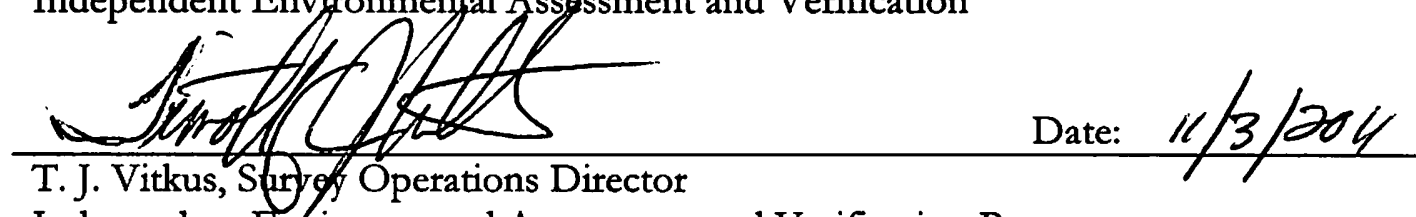
Independent Entrironmental Assessment and Verification Program

Reviewed by: Wade P. Ny $\quad$ Date: $11 / 4 / 11$ Independent Envirbnmental Assessment and Verification Program

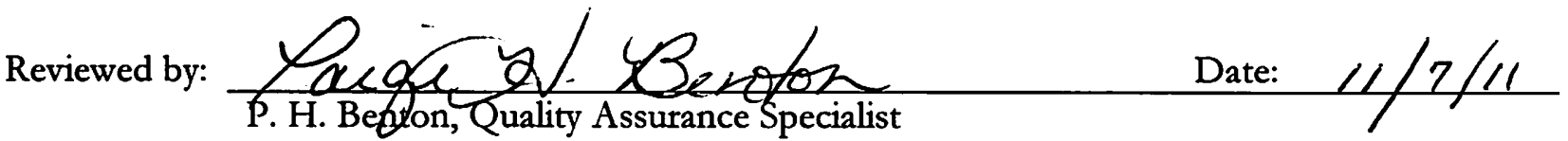
Independent Environmental Assessment and Verification Program 


\section{TABLE OF CONTENTS}

FIGURES ...ii

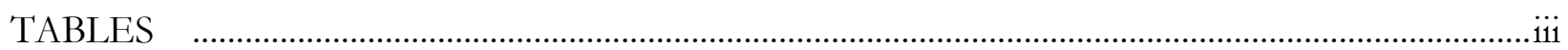

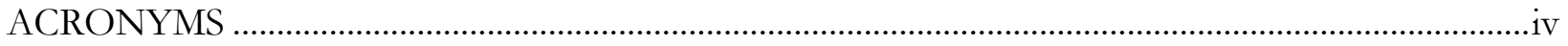

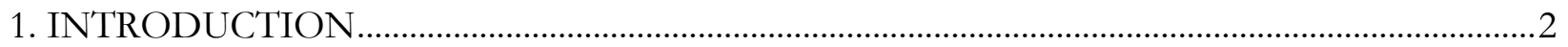

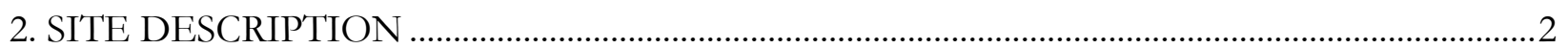

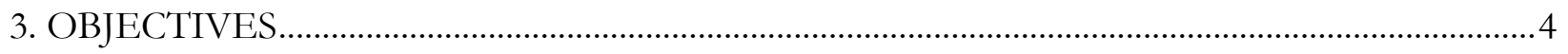

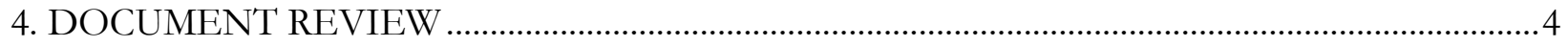

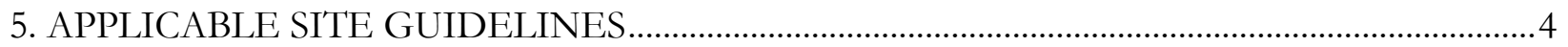

5.1 RELEASE CRITERIA FOR BUILDING SURFACES ....................................................................4

5.2 RELEASE CRITERIA FOR SOILS.........................................................................................

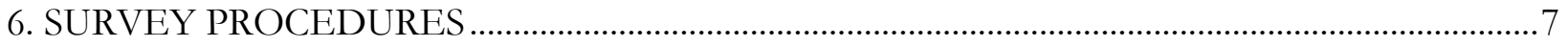

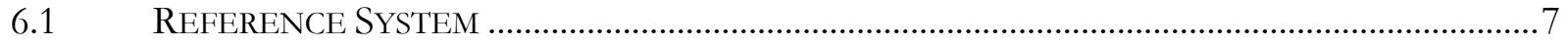

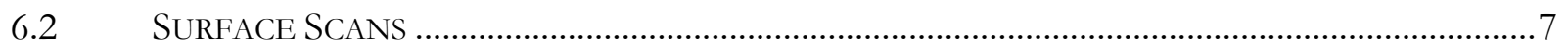

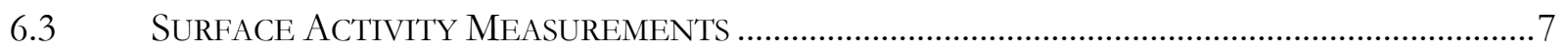

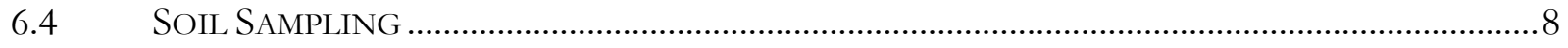

7. SAMPLE ANALYSIS AND DATA INTERPRETATION ……..................................................

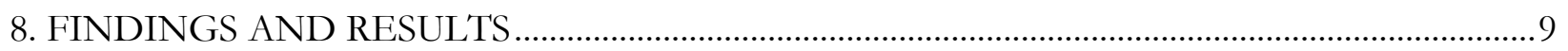

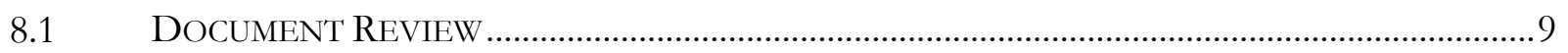

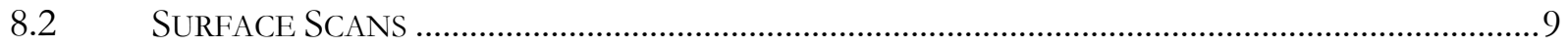

8.3 SURFACE ACTIVITY MEASUREMENTS …...............................................................................

8.4 RADIONUCLIDE CONCENTRATION IN SOIL AND CONCRETE SAMPLES ..............................11

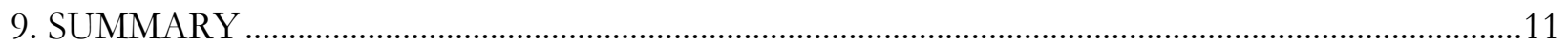

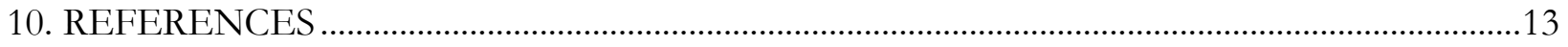

APPENDICES

APPENDIX A: FIGURES

APPENDIX B: TABLES

APPENDIX C: MAJOR INSTRUMENTATION

APPENDIX D: SURVEY AND ANALYTICAL PROCEDURES 


\section{FIGURES}

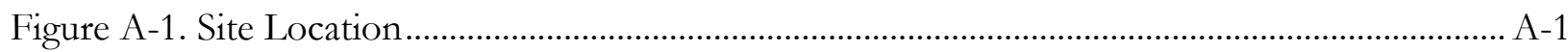

Figure A-2. Alpha plus beta scan data for Room 122 ....................................................................... A-2

Figure A-3. Alpha plus beta scan data for Room 124 .................................................................... A-3

Figure A-4. Alpha plus beta scan data for the reactor pool............................................................... A-4

Figure A-5. Alpha plus beta scan data for Room 124A …................................................................. A-5

Figure A-6. Alpha plus beta scan data for Room 216 ......................................................................... A-6 


\section{TABLES}

Table 2.1. NRL Survey Areas and MARSSIM Classification .....................................................................

Table 5.1. Applicable NRC Screening Values for Building Surfaces and Materials................................5

Table 5.2. Applicable NRC Screening Values for Soils ..........................................................................6

Table B-1. Surface Activity for All Survey Units ....................................................................................

Table B-2. Radionuclide Concentration in Soil .........................................................................................

Table B-3. Inter-Laboratory Comparison of Analytical Results in Concrete Samples ......................... B-3 


\section{ACRONYMS}

$\begin{array}{ll}\text { Co-60 } & \text { cobalt-60 } \\ \text { cpm } & \text { counts per minute } \\ \text { DCGL } & \text { derived concentration guideline level } \\ \text { DER } & \text { normalized absolute difference } \\ \text { DOE } & \text { U.S. Department of Energy } \\ \text { DP } & \text { decommissioning plan } \\ \text { dpm } & \text { disintegrations per minute } \\ \text { EMC } & \text { elevated measurement comparison } \\ \text { FSS } & \text { final status survey } \\ \text { FSSP } & \text { final status survey plan } \\ \text { GM } & \text { Geiger-Müller } \\ \text { GPS } & \text { global positioning system } \\ \text { IEAV } & \text { Independent Environmental Assessment and Verification } \\ \text { MARSSIM } & \text { Multi-Agency Radiation Survey and Site Investigation Manual } \\ \text { MDC } & \text { minimum detectable concentration } \\ \text { MeV } & \text { million electron volts } \\ \text { NRC } & \text { U.S. Nuclear Regulatory Commission } \\ \text { NRL } & \text { Nuclear Reactor Laboratory } \\ \text { ORAU } & \text { Oak Ridge Associated Universities } \\ \text { ORISE } & \text { Oak Ridge Institute for Science and Education } \\ \text { pCi/g } & \text { picocuries per gram } \\ \text { ROC } & \text { radionuclide of concern } \\ \text { SU } & \text { survey unit } \\ \text { TAP } & \text { total absorption peak } \\ \text { University } & \text { University of Arizona } \\ \text { VPP } & \text { vacuum pump pit } \\ & \end{array}$




\section{FINAL - INDEPENDENT CONFIRMATORY SURVEY REPORT FOR THE UNIVERSITY OF ARIZONA NUCLEAR REACTOR LABORATORY TUCSON, ARIZONA}

\section{INTRODUCTION}

The University of Arizona (University) research reactor is a TRIGA swimming pool type reactor designed by General Atomics and constructed at the University in 1958. The reactor first went into operation in December of 1958 under U.S. Nuclear Regulatory Commission (NRC) license R-52 until final shut down on May 18, 2010. Initial site characterization activities were conducted in February 2009 during ongoing reactor operations to assess the radiological status of the Nuclear Reactor Laboratory (NRL) excluding the reactor tank, associated components, and operating systems. Additional post-shutdown characterization activities were performed to complete characterization activities as well as verify assumptions made in the Decommissioning Plan (DP) that were based on a separate activation analysis (ESI 2009 and WMG 2009). Final status survey (FSS) activities began shortly after the issuance of the FSS plan in May 2011. The contractor completed measurement and sampling activities during the week of August 29, 2011.

At the request of the NRC, the Oak Ridge Institute for Science and Education (ORISE) conducted confirmatory survey activities at the NRL during the week of September 6, 2011. The ORISE contract is managed by Oak Ridge Associated Universities (ORAU) for the U. S. Department of Energy (DOE).

\section{SITE DESCRIPTION}

The University is centrally located in Tucson, Arizona in Pima County approximately 110 miles southeast of Phoenix and 65 miles north of the Mexican border at Nogales, Arizona (see Figure A-1). The NRL is located on the main campus within the Engineering Building on the 325 acre University campus (LVI 2011). The NRL is comprised of four adjacently located rooms with controlled access in the north wing of the Engineering Building.

The contractor classified the survey units (SUs) based on contamination potential, as either Class 1, 2, or 3 in accordance with the Multi-Agency Radiation Survey and Site Investigation Manual (MARSSIM) (NRC 2000). A description of each class designation is as follows: 
Class 1: Buildings or land areas that have a significant potential for radioactive contamination (based on site operating history) or known contamination (based on previous radiological surveys) that exceeds the expected site derived concentration guideline level (DCGL) value.

Class 2: Buildings or land areas, often contiguous to Class 1 areas that have a potential for radioactive contamination, but at levels less than the expected DCGL.

Class 3: Remaining impacted buildings and land areas that are not expected to contain residual contamination or are expected to contain levels of residual contamination at a small fraction of the DCGL.

The survey areas and classifications based on the MARSSIM are listed in Table 2.1:

\begin{tabular}{|c|c|c|}
\hline \multicolumn{2}{|c|}{ Table 2.1. NRL Survey Areas and MARSSIM Classification } \\
\hline Survey Area & \multicolumn{2}{|c|}{ MARSSIM Classification } \\
\hline Reactor Pit (sub-grade in Room 124) & 1 & All surfaces \\
\hline \multirow{2}{*}{ Room 124 (Reactor Room) } & 2 & Floor and Walls $<2 \mathrm{~m}$ \\
\cline { 2 - 3 } & 3 & Walls $>2 \mathrm{~m}$ and Ceiling \\
\hline \multirow{2}{*}{ Room 124A (Equipment and Storage Room) } & 2 & Floor and Walls $<2 \mathrm{~m}$ \\
\cline { 2 - 3 } & 3 & Walls $>2 \mathrm{~m}$ and Ceiling \\
\hline Room 122 (Reactor Control Room) & 3 & All surfaces \\
\hline Room 216 (Storage Room) & 3 & All surfaces \\
\hline
\end{tabular}

Room 124 is the Reactor Room and contains the sub-grade reactor tank, a vacuum pump pit (VPP), and six storage pits that are located east of the reactor tank.

Room 216 is positioned directly above the reactor room and was originally designed to receive a beam of neutrons from the reactor. Little use was made of the beam capability and the floor penetration to the reactor room is currently capped and locked. Additionally, the building exterior and surrounding land area is considered non-impacted except for the concrete pads (Class 2) located exterior to the north wall of the building and associated with the former filtration/ion exchange and cooling compression systems (LVI 2011). 


\section{OBJECTIVES}

The objectives of the confirmatory activities were to provide independent contractor field data reviews and to generate independent radiological data for use by the NRC in evaluating the adequacy and accuracy of the contractor's procedures and FSS results.

\section{DOCUMENT REVIEW}

Prior to on-site activities, ORISE reviewed the licensee's DP (ESI 2009). The DP was specifically reviewed for historical information, as well as to identify the radionuclides of concern (ROCs) and the applicable screening levels in order to develop the confirmatory survey plan. ORISE also reviewed the University's final status survey plan (FSSP), post shutdown characterization report, and activation analysis (LVI 2011; ESI 2010; WMG 2009). All documents were reviewed for adequacy and appropriateness, taking in to account the approved DP and MARSSIM guidance (NRC 2000).

FSS data packages were not available prior to ORISE's site visit. However, FSS data packages were reviewed following the site visit. All issues identified in the document review process are discussed in Section 8.

\section{APPLICABLE SITE GUIDELINES}

The primary contaminants of concern for the NRL are beta-gamma emitters-fission and activation products-resulting from reactor operation. Alpha contamination was not identified during the review of historical operational data or during characterization efforts. Additionally, there have been no fuel leaks at the facility, no elevated radiation levels measured from the resin in the demineralization system, or any indications of alpha contamination in historical survey data (ESI 2010). During remediation of the reactor, additional concrete characterization samples (cores) were collected from the tank wall and floor. These samples indicated that the only radionuclides of concern were europium-152, cobalt-60 (Co-60), and tritium (LVI 2011).

\subsection{Release Criteria For Building Surfaces}

The NRC screening values for building surfaces and materials destined to remain in place have been approved as the release criteria and are listed in Table 5.1. The screening values presented in Table 5.1 were used to evaluate FSS measurements to determine compliance with the $25 \mathrm{mrem} / \mathrm{yr}$ unrestricted use criterion (10 CFR 20.1402). However, since the most restrictive release criterion for 
the isotopes detectable with field survey instruments is Co-60, the FSSP directs that all measurable activity is assumed to be Co-60 and a single release criterion of 7,100 dpm/100 $\mathrm{cm}^{2}$ applies for total measureable beta activity. Additionally, the screening criteria are based on the assumption that the fraction of removable surface contamination is equal to 0.1 . Therefore, removable surface contamination results must be less than or equal to $10 \%$ of the screening values. Since the FSSP directs the application of the Co-60 release criterion of 7,100 dpm/100 $\mathrm{cm}^{2}$, the removable contamination release criterion is $710 \mathrm{dpm} / 100 \mathrm{~cm}^{2}$ (LVI 2011).

\begin{tabular}{|c|c|}
\hline $\begin{array}{c}\text { Table 5.1. Applicable NRC Screening Values } \\
\text { for Building Surfaces and Materials }\end{array}$ \\
\hline Radionuclide & $\begin{array}{c}\text { Screening Level for Unrestricted } \\
\text { Release (dpm/100 } \mathbf{~ c m}^{\mathbf{2}} \text { ) }\end{array}$ \\
\hline Tritium (H-3) & $1.2 \mathrm{E}+08$ \\
\hline Carbon-14 & $3.7 \mathrm{E}+06$ \\
\hline Manganese-54 & $3.2 \mathrm{E}+04$ \\
\hline Iron-55 & $4.5 \mathrm{E}+06$ \\
\hline Cobalt-60 & $7.1 \mathrm{E}+03$ \\
\hline Nickel-63 & $1.8 \mathrm{E}+06$ \\
\hline Technetium-99 & $1.3 \mathrm{E}+06$ \\
\hline Cesium-137 & $2.8 \mathrm{E}+04$ \\
\hline
\end{tabular}

aValues reproduced from NUREG-1757 Vol. 1., Rev. 2.

\subsection{RELEASE CRITERIA FOR SOILS}

The NRC screening values applicable for soils are listed in Table 5.2. The NRC screening value for europium-152 was lowered to the Environmental Protection Agency and NRC Memorandum of Understanding consultation trigger value. There has been no indication that the subsurface soils have been impacted by activities at the NRL; however, the activation analysis did indicate that soil within the neutron flux field of the reactor could potentially contain Co-60 from the activation of Co-59 in the soil. Additionally, demolition activities associated with the reactor tank could have introduced other radionuclides of concern into the surface area of the soils (LVI 2011).

Because the concrete cores of the reactor tank indicated volumetric radioactive contamination throughout a significant portion of the cores, as opposed to surface contamination and there were structural safety concerns about removing all of the lower tank concrete to background levels, 
discussions were held with the NRC on alternative options. Following those discussions, the University submitted a request for revision to the DP to apply the NRC soil screening values to residual concrete in the reactor tank. Based on the analytical results of tank concrete core samples, tank remediation can be conducted to meet the soil release criteria without compromising the structural integrity of the tank (LVI 2011).

\begin{tabular}{|c|c|}
\hline \multicolumn{2}{|c|}{$\begin{array}{l}\text { Table 5.2. Applicable NRC Screening Values } \\
\text { for Soils }{ }^{a}\end{array}$} \\
\hline Radionuclide & $\begin{array}{l}\text { Screening Level for Unrestricted } \\
\text { Release }(\mathrm{pCi} / \mathrm{g})^{\mathrm{b}}\end{array}$ \\
\hline Cobalt-60 & 3.8 \\
\hline Tritium (H-3) & 110 \\
\hline Carbon-14 & 12 \\
\hline Iron-55 & 10,000 \\
\hline Nickel-63 & 2,100 \\
\hline Cesium-137 & 11 \\
\hline Europium-152 & $7 \mathrm{c}$ \\
\hline Europium-154 & 8 \\
\hline Calcium-45 & 57 \\
\hline Chromium-51 & N/A (Half-Life 27.7 days) \\
\hline Iron-59 & N/A (Half-Life 44.5 days) \\
\hline Cobalt-58 & N/A (Half-Life 70.9 days) \\
\hline Nickel-59 & 5,500 \\
\hline Zinc-65 & Cobalt- 60 as surrogate \\
\hline Niobium-94 & Cobalt-60 as surrogate \\
\hline
\end{tabular}

aValues reproduced from NUREG-1757 Vol. 1., Rev 2. These values represent surficial surface soil concentrations of individual radionuclides that would be deemed in compliance with the $25 \mathrm{mrem} / \mathrm{yr}$ unrestricted release dose limit in 10 CFR 20.1402. For radionuclides in a mixture, the "sum of fractions" rule applies.

${ }^{\mathrm{b}} \mathrm{pCi} / \mathrm{g}=$ picocuries per gram.

'The Eu-152 NRC screening value is greater than the Environmental Protection Agency and NRC

Memorandum of Understanding consultation trigger value of $7 \mathrm{pCi} / \mathrm{g}$; therefore the lower value was selected. 


\section{SURVEY PROCEDURES}

At the request of the NRC, the ORISE survey team visited the University September 6 and 7, 2011, to perform confirmatory survey activities, which included visual inspections; surface scans; surface activity measurements; and sample collection. The confirmatory survey activities were conducted in accordance with a project-specific plan, the ORISE/Independent Environmental Assessment and Verification (IEAV) Survey Procedures Manual and Quality Program Manual (ORISE 2011b, ORISE 2008, ORAU 2011). Appendix D provides a detailed outline of the survey procedures and analytical methods used. Questions and concerns were brought to the immediate attention of the NRC and are also noted in the Findings and Results section of this report.

\subsection{REFERENCE SYSTEM}

Measurements and sampling locations were referenced to prominent site features and documented on site drawings provided by the licensees.

\subsection{SURFACE SCANS}

Gamma scans were performed using $\mathrm{NaI}(\mathrm{Tl})$ scintillation detectors coupled to ratemeter-scalers with audible indicators. Alpha plus beta surface scans were performed using hand-held gas proportional detectors, and Geiger-Müller (GM) detectors coupled to ratemeter-scalers with audible indicators. Gas proportional detector/instrument combinations were connected to hand-held data loggers, which allowed the recording of alpha plus beta radiation count rate response.

Scan coverage for each SU was based on the MARSSIM classification presented in Table 2.1. Class 3 surfaces received low density coverage; Class 2 surfaces received medium density coverage; and Class 1 surfaces received high density coverage. Remaining equipment such as sinks/drains and ventilation systems remaining in each SU were also investigated, with the exception of the reactor control console.

\subsection{SURFACE ACTIVITY MEASUREMENTS}

Based on alpha plus beta scan results, direct measurements for alpha plus beta activity were performed at 19 judgmentally selected locations within the NRL. The locations were selected based on the highest radiation level identified by the ORISE survey team. Direct measurements were performed by using hand-held gas proportional detectors coupled to ratemeter-scalers. As a 
conservative approach, as employed by the contractor, material specific backgrounds were not collected. A smear sample for gross alpha and beta activity levels, as well as a smear for tritium and carbon-14 (C-14), was collected from each direct measurement location.

\subsection{SOIL SAMPLING}

One soil sample was collected from the VPP beside the reactor, on the south edge of the reactor tank. Most of the soil in the VPP had been removed during a sewer repair and staged outside. However, the soil sample was collected from an undisturbed area.

Additionally, the contractor collected and provided three split concrete samples from the reactor pool for an inter-lab comparison, as requested by the NRC. The results of the ORISE lab analysis were also compared to the screening value for soils. The normalized absolute difference (DER) is used to determine if two samples differ significantly from one another (DOE 2010).

\section{SAMPLE ANALYSIS AND DATA INTERPRETATION}

Samples and data collected were returned to the ORISE facility in Oak Ridge, Tennessee for analysis and interpretation. All sample analyses were performed in accordance with the ORISE Laboratory Procedures Manual (ORISE 2011a). The soil and concrete samples were analyzed by solid-state gamma spectroscopy for gamma-emitting ROCs. Analytical results for soil were reported in units of picocuries per gram (pCi/g). Smears for gross alpha and gross beta were analyzed using a low background gas flow-through proportional counter. Smears for tritium and C-14 were analyzed by liquid scintillation analysis. Analytical smear sample results were reported in units of disintegrations

per minute per one hundred square centimeters $\left(\mathrm{dpm} / 100 \mathrm{~cm}^{2}\right)$. Direct measurement data were converted from counts per minute $(\mathrm{cpm})$ to units of $\mathrm{dpm} / 100 \mathrm{~cm}^{2}$. The data generated were compared with the approved NRC screening values (Tables 5.1 and 5.2). The difference between the lab's results was determined to be acceptable if the following condition was met:

$$
\frac{|S-D|}{\sqrt{U_{S}{ }^{2}+U_{D}{ }^{2}}} \leq 3(\text { DOE } 2010)
$$

$$
\begin{array}{ll}
\text { Where: } & \mathrm{S}=\text { Sample result } \\
\mathrm{D}=\text { Duplicate (confirmatory) result } \\
\mathrm{U}_{\mathrm{S}}=\text { Uncertainty of the sample } \\
\mathrm{U}_{\mathrm{D}}=\text { Uncertainty of the duplicate (confirmatory) result }
\end{array}
$$




\section{FINDINGS AND RESULTS}

The results for each of the confirmatory activities are discussed in the following subsections.

\subsection{Document Review}

The ORISE project manager did not find any issues with the documents reviewed prior to confirmatory survey activities. After reviewing the post shutdown characterization report and activation analysis, ORISE is in agreement with the contractor's decision to eliminate the costly sample analysis of C-14 and iron-55, due to the fact these were not identified in the characterization sampling efforts. No issues were identified during review of the FSSP. The only issue identified during the document review process was with calculation of surface activity in the FSS data packages, which is discussed further in section 8.3.

\subsection{SURFACE SCANS}

Appendix A (Figures A-2 through A-6) provide the survey and data summaries for each SU.

Quantile-quantile (Q-Q) plots of each survey area's floor and wall direct radiation measurement data are used to illustrate the radiation level population distributions. In viewing the Q-Q plots provided in Appendix A, the $\mathrm{Y}$-axis represents cpm. The $\mathrm{X}$-axis represents the data quantiles about the mean value. A normal distribution that is not skewed by outliers - a background radiation populationwill appear as a straight line, with the slope of the line subject to the degree of variability among the data population. Values less than the mean are represented in the negative quantiles and the values greater than the mean are represented in the positive quantiles. The advantages of the Q-Q plot are as follows:

Population distributional aspects can be evaluated simultaneously. The aspects that can all be detected include:

a) shifts in scale,

b) changes in symmetry (skewness of the data), and

c) the presence of outliers.

d) Do two data sets have similar tail behavior (left or right skew, i.e. outliers)? 
The data sets for walls and floors do not match in every SU because of different construction materials. Instrument response for alpha plus beta scans ranged from 160 to 1,200 cpm, over all SUs. Room 124A had the highest average instrument response for walls, due to brick containing natural thorium. The highest average instrument response for the floors also occurred in Room 124A.

The ORISE survey team detected two areas of elevated radioactivity in excess of the Co-60 screening value when performing gamma and alpha plus beta surface scans. The first area was the supply vents located inside Room 124 (instrument response for the vents was not logged). However, the ORISE survey team was confident that the activity was due to radon and its decay progeny.

The second area in excess of the Co-60 limit was identified while performing scans of the source pits with a hand-held GM probe. An area of elevated direct radiation was identified in source pit number 2, prompting further investigation (discussed in section 8.3).

\subsection{Surface ACTIVITy MEASUREMENTS}

Total surface activity and removable activity levels for the 19 judgmentally determined measurement locations are presented in Table B-1. Following a conservative approach employed by the contractor, gross counts were not corrected for material-specific backgrounds when calculating surface activity. Instead, ambient background for the instruments was used as opposed to determining material-specific backgrounds. Total surface activity in all SUs ranged from 490 to $15,000 \mathrm{dpm} / 100 \mathrm{~cm}^{2}$. The highest surface activity was found in source pit number 2 and was not previously identified by the contractor. Assuming the contamination was the result of Co- 60 , the judgmental direct measurement exceeded the screening value. The NRC requested remediation of the area for as low as reasonably achievable purpose. Post-remediation data documented a surface activity of 2,900 dpm/100 $\mathrm{cm}^{2}$ due to cesium-137. Even though the contamination was identified as cesium-137, which has a higher screening level than Co-60, the surface activity still meets the Co-60 screening level. The second highest surface activity was measured in the reactor pool, but was well below the Co-60 screening level.

Laboratory analysis of the smears did not identify removable contamination above background for the 19 direct measurement locations. Removable activity across all SUs for gross alpha ranged from 0 to $4 \mathrm{dpm} / 100 \mathrm{~cm}^{2}$ and -3 to $6 \mathrm{dpm} / 100 \mathrm{~cm}^{2}$ for gross beta. Removable activity for the 
hard-to-detect radionuclides ranged from -7 to $6 \mathrm{dpm} / 100 \mathrm{~cm}^{2}$ for tritium and -2 to $4 \mathrm{dpm} / 100 \mathrm{~cm}^{2}$ for C-14 across all SUs.

The licensee's FSS draft data packages were reviewed, following the site visit. The licensee's reported surface activity levels were approximately one-half of the confirmatory results. Upon further investigation, ORISE determined that the contractor performing the FSS was using a 0.5 surface efficiency for Co-60. Per NUREG-1507, the default surface efficiency for Co-60 would be 0.25 and should be applied for Co-60 as the primary beta energy is less than $400 \mathrm{keV}$ (NRC 1997). After applying a surface efficiency of 0.25 , the licensee's data is more comparable to the values in this report.

\subsection{RADIONUClide CONCENTRATION IN SOIL AND CONCRETE SAMPLES}

Analytical results for the soil sample collected are presented in Table B-2. The ROC concentrations are below the screening values for soil.

Table B-3 presents the results of the inter-lab comparison. One of the three samples did not pass the DER criteria test for significant difference for all analytes. The DER for tritium on sample 2051M0002 is 6.3, which indicates a significant difference between data reported by ORISE and the licensee. This difference could be explained by the fact that the ORISE lab did not analyze the same sample, as they were split samples. However, the tritium concentrations are below the screening levels.

\section{SUMMARY}

At the request of the NRC, ORISE conducted confirmatory survey activities within the NRL at the University during the week of September 6, 2011. The survey activities included visual inspections/assessments, gamma measurements, alpha plus beta measurements, smear sampling, and soil sampling activities.

As a result of the confirmatory activities, ORISE noted two issues with FSS activities performed at the University. The first was the area of residual activity above the Co-60 screening level in source pit number 2. Since confirmatory surveys occurred, surface activity in source pit 2 has been remediated to a value below the Co-60 screening level. The second issue identified by ORISE was 
use of an incorrect surface efficiency. As a result, the contractor has agreed to re-calculate surface activity using a surface efficiency of 0.25 , the correct value for Co- 60 .

Because the two issues described have been resolved since the confirmatory surveys, ORISE is of the opinion that the FSS data has adequately and accurately demonstrated that the NRL is below the appropriate screening levels. Confirmatory survey activities validate the licensee's conclusion that the appropriate guidelines have been met. 


\section{REFERENCES}

Enercon Services, Inc. (ESI). University of Arizona Nuclear Reactor Laboratory Decommissioning Plan, Revision 0. Murrysville, Pennsylvania. May 21, 2009.

Enercon Services, Inc. University of Arizona Nuclear Reactor Laboratory Post Shutdown Radiological Characterization Report. Murrysville, Pennsylvania. October 12, 2010.

LVI Environmental Services, Inc. (LVI). Final Status Survey Plan, University of Arizona Nuclear Reactor Laboratory, Facility Operating License R-52. Revision 1. Shawnee, Oklahoma. August 1, 2011.

Oak Ridge Associated Universities (ORAU). Quality Program Manual for the Independent Environmental Assessment and Verification Program. Oak Ridge, Tennessee. May 10, 2011.

Oak Ridge Institute for Science and Education (ORISE). Survey Procedures Manual for the Independent Environmental Assessment and Verification Program. Oak Ridge, Tennessee. May 1, 2008.

Oak Ridge Institute for Science and Education. Laboratory Procedures Manual for the Independent Environmental Assessment and Verification Program. Oak Ridge, Tennessee. April 28, 2011a.

Oak Ridge Institute of Science and Education. Project-Specific Plan for Independent Confirmatory Survey Activities Associated With the University of Arizona Nuclear Reactor Laboratory, Tucson, Arizona. Oak Ridge, Tennessee. August 31, 2011b.

U.S. Department of Energy (DOE). Quality Systems for Analytical Services, Revision 2.6. November, 2010.

U.S. Nuclear Regulatory Commission (NRC). Minimum Detectable Concentrations with Typical Radiation Survey Instruments for Various Contaminants and Field Conditions, NUREG-1507. Washington, DC. August, 1997.

U.S. Nuclear Regulatory Commission. Multi-Agency Radiation Survey and Site Investigation Manual (MARSSIM), NUREG-1575; Revision 1. Washington, DC. August, 2000.

U.S. Nuclear Regulatory Commission. Consolidated Decommissioning Guidance, Decommissioning Process for Materials Licensees, NUREG-1757 Vol. 1, Rev. 2. Washington, DC. September, 2006.

WMG, Inc. (WMG). University of Arizona Activation Analysis and Component Characterization; Revision 0. Peekskill, NY. May, 2009. 
APPENDIX A

FIGURES 


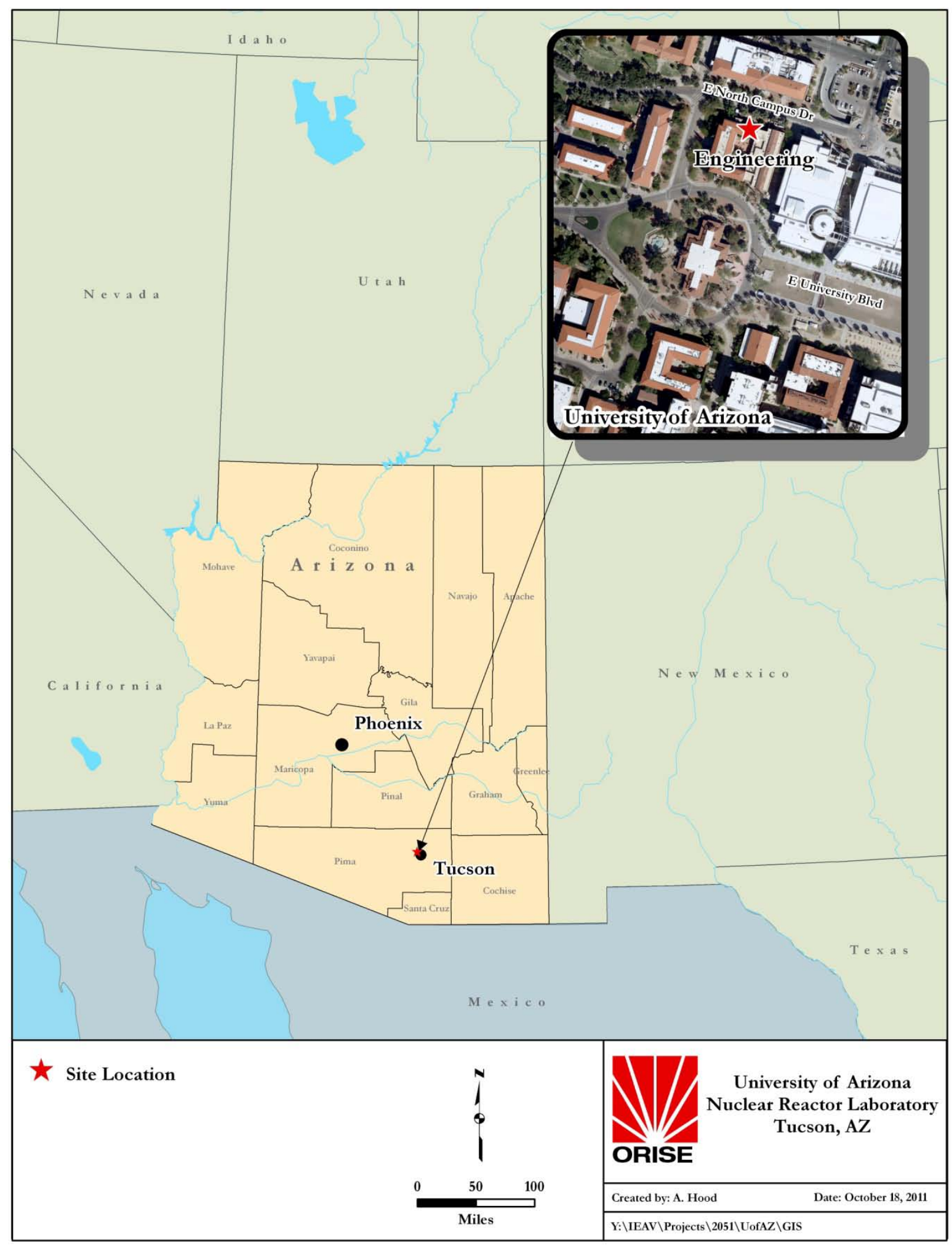

Figure A-1. Site Location 


\begin{tabular}{|c|c|c|c|c|c|c|}
\hline \multicolumn{7}{|c|}{ SUMMARY STATISTICS FOR RM 122 (cpm) } \\
\hline Structure & $\mathbf{n}$ & Min & Max & Mean & Median & SD \\
\hline Walls & 785 & 224 & 772 & 438.5 & 439 & 96.62 \\
Floor & 494 & 203 & 724 & 439.8 & 441 & 99.98 \\
\hline
\end{tabular}

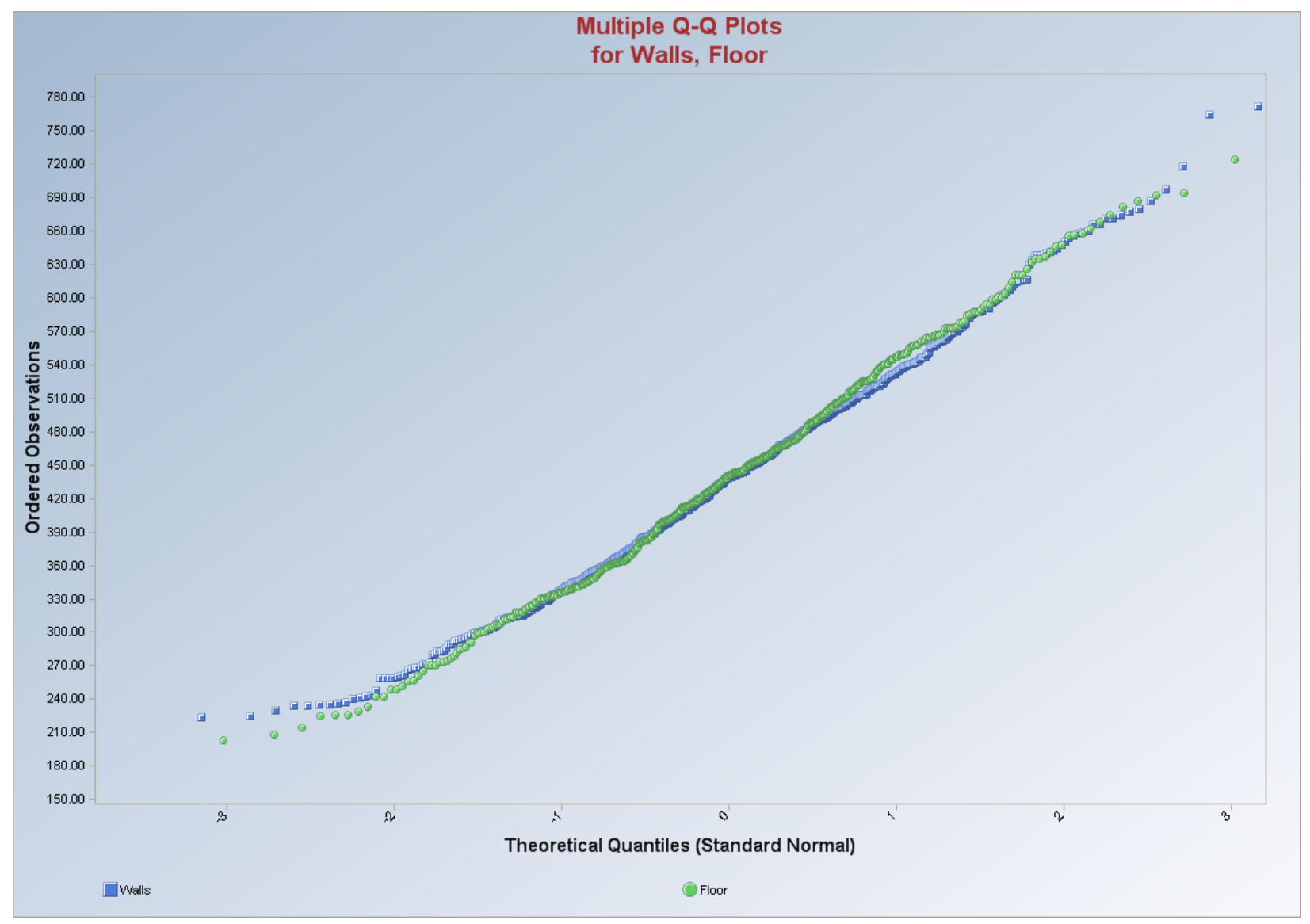

Figure A-2. Alpha plus beta scan data for Room 122 


\begin{tabular}{|c|c|c|c|c|c|c|}
\hline \multicolumn{7}{|c|}{ SUMMARY STATISTICS FOR RM 124 (cpm) } \\
\hline Structure & $\mathbf{n}$ & Min & Max & Mean & Median & SD \\
\hline Walls & 1410 & 382 & 1190 & 758.4 & 755 & 125.2 \\
Floor & 623 & 222 & 857 & 499.6 & 490 & 102.5 \\
\hline
\end{tabular}

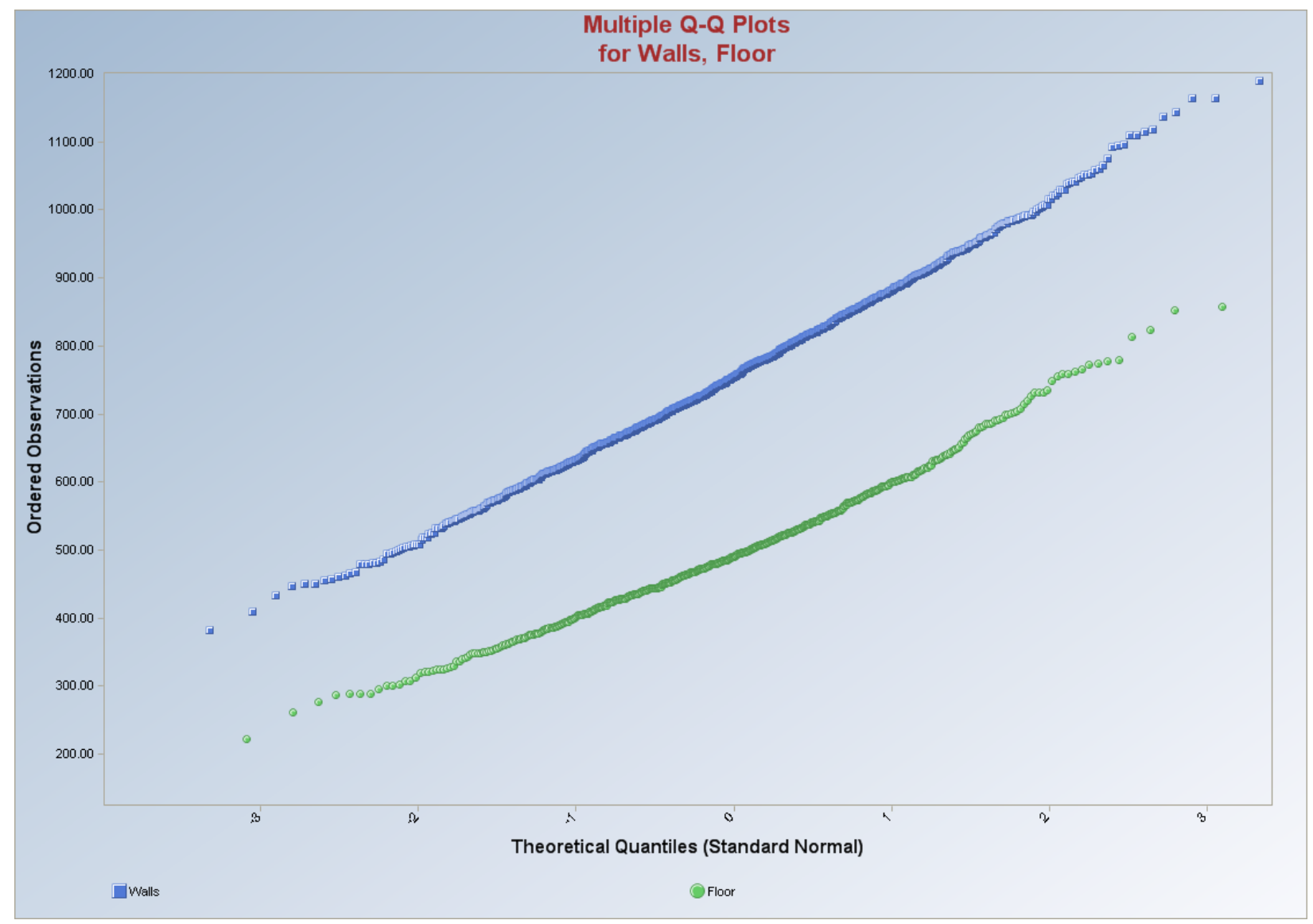

Figure A-3. Alpha plus beta scan data for Room 124 


\begin{tabular}{|c|c|c|c|c|c|c|}
\hline \multicolumn{6}{|c|}{ SUMMARY STATISTICS FOR THE REACTOR POOL (cpm) } \\
\hline Structure & $\mathbf{n}$ & Min & Max & Mean & Median & SD \\
\hline Walls & 396 & 157 & 641 & 354.6 & 342 & 97.09 \\
Floor & 1223 & 276 & 1055 & 640.5 & 637 & 117.5 \\
\hline
\end{tabular}

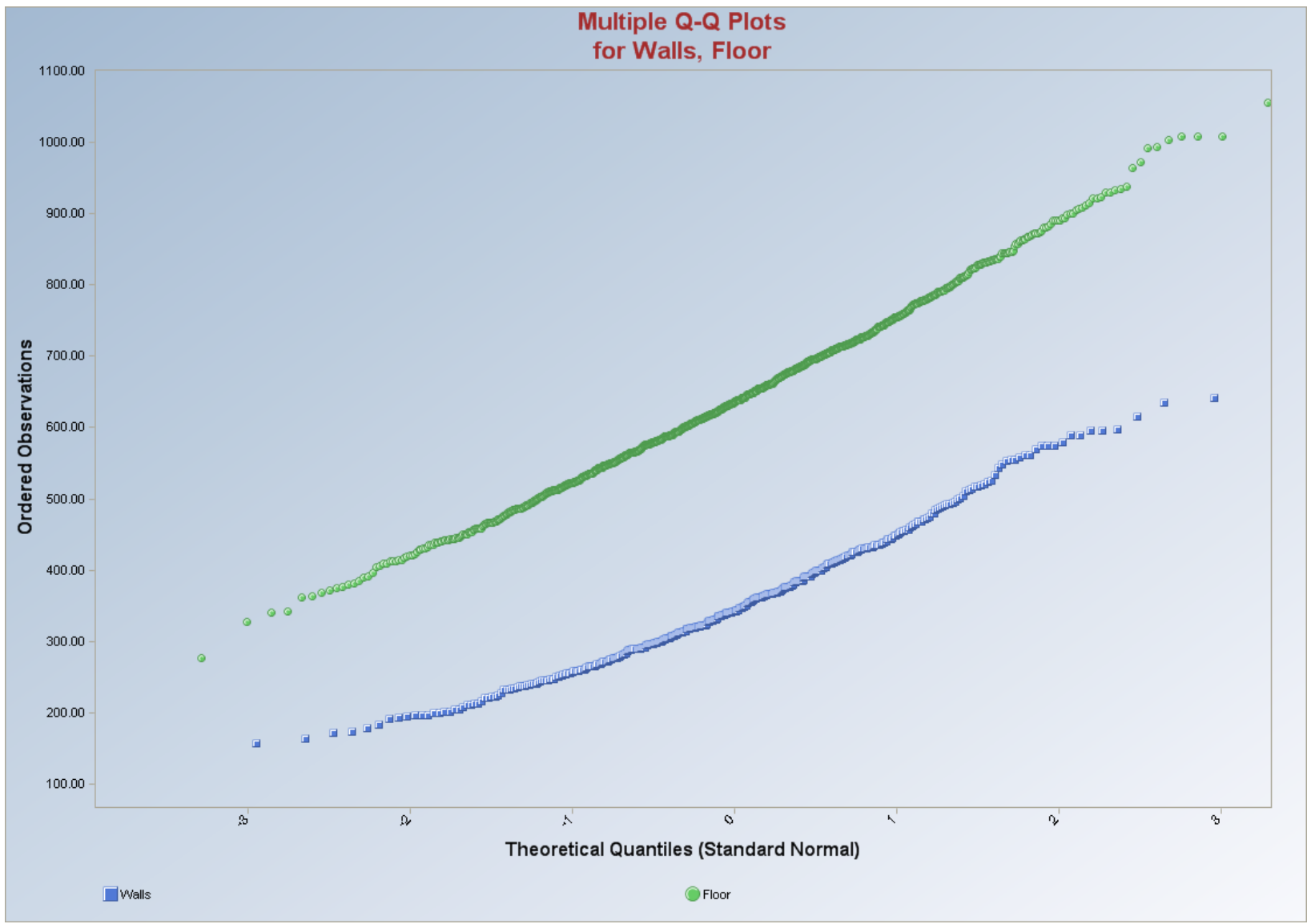

Figure A-4. Alpha plus beta scan data for the reactor pool 


\begin{tabular}{|c|c|c|c|c|c|c|}
\hline \multicolumn{7}{|c|}{ SUMMARY STATISTICS FOR RM 124A (cpm) } \\
\hline Structure & $\mathbf{n}$ & Min & Max & Mean & Median & SD \\
\hline Walls & 1410 & 382 & 1190 & 758.4 & 755 & 125.2 \\
Floor & 589 & 329 & 885 & 601.2 & 596 & 101.4 \\
\hline
\end{tabular}

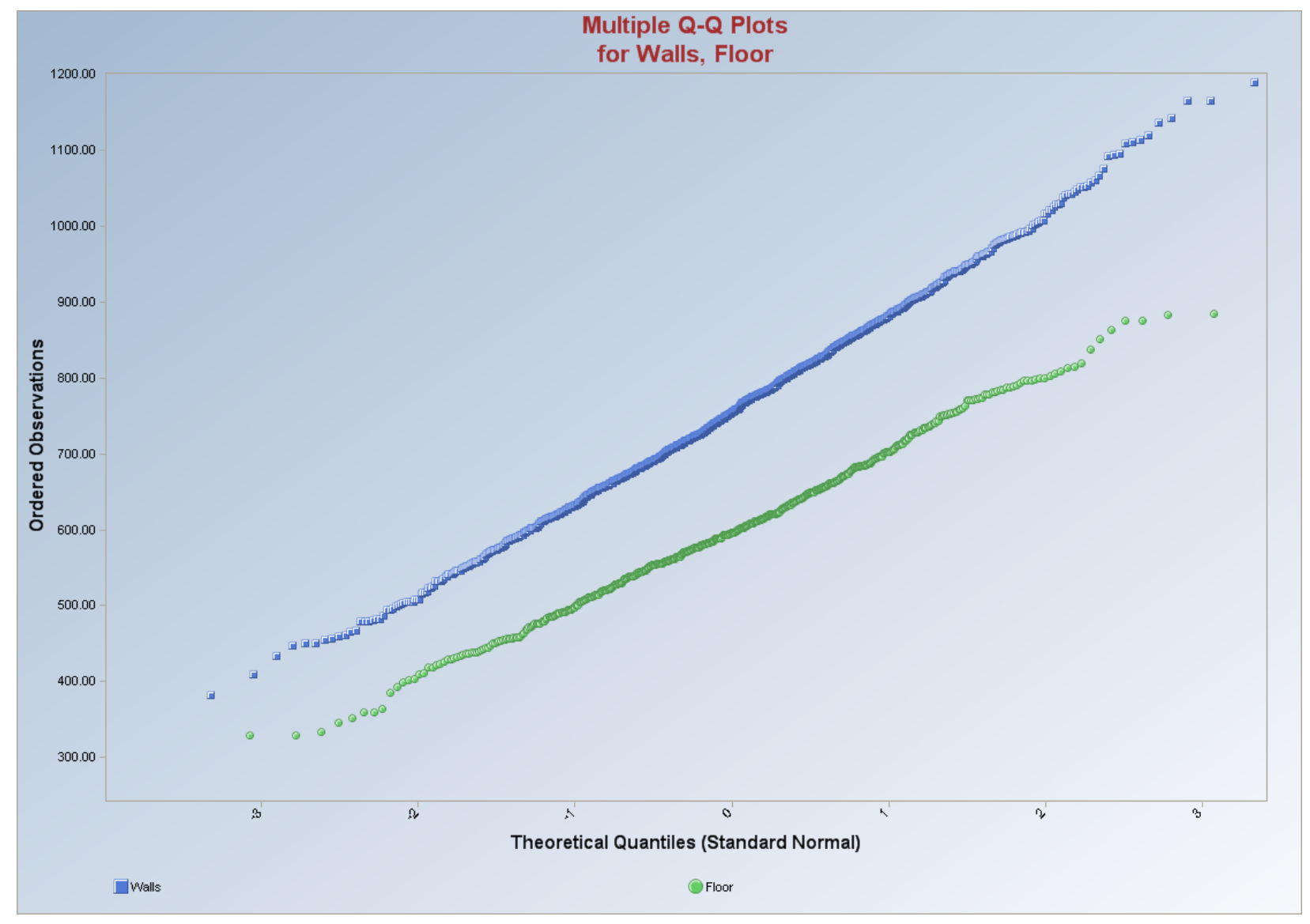

Figure A-5. Alpha plus beta scan data for Room 124A 


\begin{tabular}{|c|c|c|c|c|c|c|}
\hline \multicolumn{7}{|c|}{ SUMMARY STATISTICS FOR RM $216(\mathrm{cpm})$} \\
\hline Structure & $\mathbf{n}$ & Min & Max & Mean & Median & SD \\
\hline Walls & 915 & 312 & 1091 & 653.5 & 638 & 149 \\
Floor & 416 & 292 & 793 & 557.1 & 550.5 & 94.93 \\
\hline
\end{tabular}

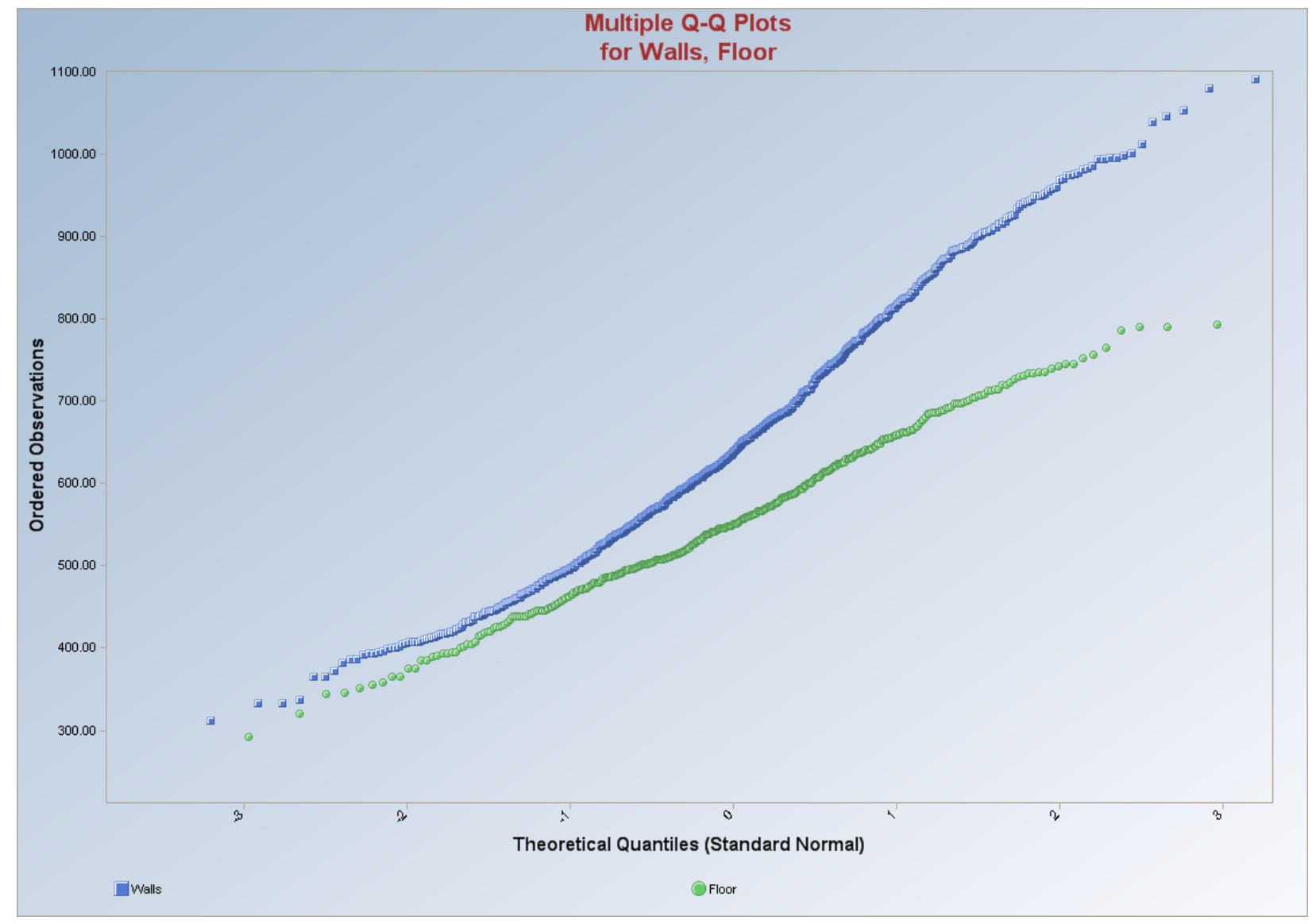

Figure A-6. Alpha plus beta scan data for Room 216 
APPENDIX B

\section{TABLES}




\section{Table B-1. Surface Activity for All Survey Units}

\begin{tabular}{|c|c|c|c|c|c|c|c|c|c|}
\hline \multirow[b]{2}{*}{ Survey Unit } & \multirow[b]{2}{*}{ Surface } & \multicolumn{2}{|c|}{ Smear \# } & \multirow{2}{*}{$\begin{array}{l}\text { 1-Minute } \\
\text { Count }\end{array}$} & \multicolumn{5}{|c|}{ Activity (dpm 100/ $\left.\mathrm{cm}^{2}\right)$} \\
\hline & & $\alpha, \beta$ & $\begin{array}{l}\mathrm{H}-3, \\
\mathrm{C}-14\end{array}$ & & $\begin{array}{c}\text { Surface } \\
(\alpha+\beta)\end{array}$ & $\begin{array}{c}\text { Removable } \\
(\alpha)\end{array}$ & $\begin{array}{c}\text { Removable } \\
(\beta)\end{array}$ & $\mathrm{H}-3(\beta)$ & C-14 ( $\beta)$ \\
\hline \multirow{3}{*}{$\operatorname{Rm} 122$} & S. Wall & 67 & 94 & 540 & 1200 & 0 & 1 & 3 & 0 \\
\hline & W. Wall & 69 & 92 & 438 & 490 & 0 & -2 & -2 & 1 \\
\hline & Floor & 68 & 93 & 445 & 540 & 0 & -2 & -2 & -1 \\
\hline \multirow{4}{*}{$\mathrm{Rm} 124$} & E. Wall & 64 & 97 & 567 & 1400 & 0 & -2 & 0 & -2 \\
\hline & S. Wall & 65 & 96 & 521 & 1100 & 0 & -2 & 1 & 1 \\
\hline & Floor & 66 & 95 & 507 & 990 & 0 & -3 & -3 & 1 \\
\hline & Source Pit 2 & 79 & 82 & 268 & 15000 & 2 & -1 & 1 & 3 \\
\hline \multirow{3}{*}{ Reactor Pool } & $\mathrm{N} / \mathrm{A}$ & 76 & 85 & 824 & 3300 & 0 & 6 & -3 & 0 \\
\hline & $\mathrm{N} / \mathrm{A}$ & 77 & 84 & 786 & 3000 & 0 & -2 & 6 & 4 \\
\hline & $\mathrm{N} / \mathrm{A}$ & 78 & 83 & 752 & 2800 & 4 & 1 & 0 & -2 \\
\hline \multirow{3}{*}{$\mathrm{Rm} 124 \mathrm{~A}$} & E. Wall & 62 & 99 & 780 & 3000 & 2 & 3 & -3 & 0 \\
\hline & E. Wall & 63 & 98 & 780 & 3000 & 0 & -2 & 2 & 2 \\
\hline & Floor & 61 & 100 & 608 & 1700 & 2 & 3 & -2 & 2 \\
\hline \multirow{3}{*}{ Rm 216} & N. Wall & 70 & 91 & 548 & 1300 & 0 & -3 & -2 & 2 \\
\hline & W. Wall & 72 & 89 & 807 & 3200 & 0 & 1 & -7 & 0 \\
\hline & Floor & 71 & 90 & 520 & 1100 & 0 & -3 & -2 & -1 \\
\hline \multirow{3}{*}{ Outdoor } & Larger Pad & 73 & 88 & 668 & 2200 & 0 & -2 & 1 & -1 \\
\hline & Larger Pad & 74 & 87 & 703 & 2400 & 0 & -1 & -2 & -1 \\
\hline & Smaller Pad & 75 & 86 & 628 & 1900 & 0 & -1 & -7 & -2 \\
\hline
\end{tabular}


Table B-2. Radionuclide Concentration in Soil

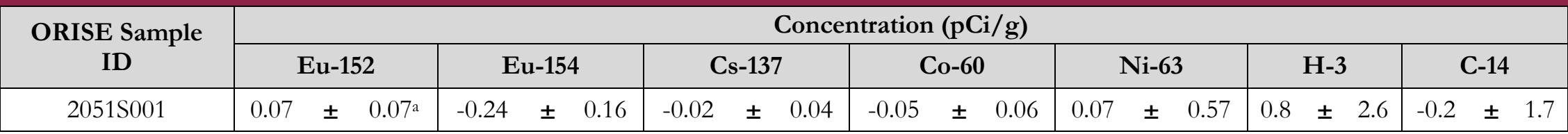

aUncertainties are reported at the $95 \%$ confidence interval 
Table B-3. Inter-Laboratory Comparison of Analytical Results in Concrete Samples

\begin{tabular}{|c|c|c|c|c|c|c|c|c|c|c|c|c|c|}
\hline \multirow{2}{*}{\multicolumn{2}{|c|}{ Sample ID }} & \multicolumn{12}{|c|}{ Radionuclide Concentrations (pCi/g) } \\
\hline & & \multicolumn{5}{|c|}{ Eu-152 } & \multirow{2}{*}{ DER } & \multicolumn{5}{|c|}{ Eu-154 } & \multirow{2}{*}{ DER } \\
\hline ORISE & Enercon & \multicolumn{2}{|c|}{ ORISE } & \multicolumn{3}{|c|}{ Enercon } & & \multicolumn{2}{|c|}{ ORISE } & \multicolumn{3}{|c|}{ Enercon } & \\
\hline 2051M0001 & Pit - 1S & 0.47 & $\pm \quad 0.09 \mathrm{a}$ & 0.561 & \pm & $0.142^{\mathrm{a}}$ & 0.54 & -0.03 & \pm 0.23 & 0.396 & \pm & 0.114 & 1.7 \\
\hline 2051M0002 & Pit - 6S & 5.00 & $\pm \quad 0.36$ & 4.69 & \pm & 0.266 & 0.69 & 0.57 & \pm 0.18 & 0.319 & \pm & 0.165 & 1.0 \\
\hline $2051 \mathrm{M} 0003$ & Pit - 9S & 0.37 & 0.09 & 0.763 & \pm & 0.187 & 1.89 & -0.21 & \pm 0.29 & 0.336 & \pm & 8.37E-02 & 1.8 \\
\hline \multicolumn{2}{|c|}{ Sample ID } & \multicolumn{5}{|c|}{ Co-60 } & \multirow{2}{*}{ DER } & \multicolumn{5}{|c|}{ Cs-137 } & \multirow{2}{*}{ DER } \\
\hline ORISE & Enercon & \multicolumn{2}{|c|}{ ORISE } & \multicolumn{3}{|c|}{ Enercon } & & \multicolumn{2}{|c|}{ ORISE } & \multicolumn{3}{|c|}{ Enercon } & \\
\hline 2051M0001 & Pit - 1S & 0.06 & $\pm \quad 0.10$ & 7.38E-03 & \pm & $3.65 \mathrm{E}-02$ & 0.49 & -0.03 & \pm 0.07 & $-9.99 \mathrm{E}-03$ & \pm & $3.43 \mathrm{E}-02$ & 0.26 \\
\hline 2051M0002 & Pit - 6S & 0.53 & $\pm \quad 0.08$ & 4.47E-01 & \pm & 6.69E-02 & 0.80 & -0.02 & \pm 0.08 & $-1.57 \mathrm{E}-02$ & \pm & 4.60E-02 & 0.05 \\
\hline 2051M0003 & Pit - 9S & 0.08 & 0.10 & $3.60 \mathrm{E}-02$ & \pm & $5.02 \mathrm{E}-02$ & 0.39 & 0.05 & 0.07 & $-9.65 E-03$ & \pm & $4.06 \mathrm{E}-02$ & 0.74 \\
\hline \multicolumn{2}{|c|}{ Sample ID } & \multicolumn{5}{|c|}{$\mathrm{H}-3$} & \multirow{2}{*}{ DER } & & & & & & \\
\hline ORISE & Enercon & \multicolumn{2}{|c|}{ ORISE } & \multicolumn{3}{|c|}{ Enercon } & & & & & & & \\
\hline 2051M0001 & Pit - 1S & 5.1 & \pm 2.9 & 2.18 & \pm & 0.638 & 1.0 & & & & & & \\
\hline 2051M0002 & Pit - 6S & 41.4 & 5.2 & 8.01 & \pm & 0.863 & 6.3 & & & & & & \\
\hline $2051 \mathrm{M} 0003$ & Pit - 9S & 6.8 & 2.9 & 2.16 & \pm & 0.759 & 1.5 & & & & & & \\
\hline
\end{tabular}

aUncertainties are reported at the $95 \%$ confidence interval 
APPENDIX C

MAJOR INSTRUMENTATION 
The display of a specific product is not to be construed as an endorsement of the product or its manufacturer by the author or her employer.

\section{C.1 SCANNING AND MEASUREMENT INSTRUMENT/DETECTOR COMBINATIONS}

\section{C.1.1 GAMMA}

Ludlum NaI Scintillation Detector Model 44-10, Crystal: $5.1 \mathrm{~cm}$ x $5.1 \mathrm{~cm}$

(Ludlum Measurements, Inc., Sweetwater, TX)

coupled to:

Ludlum Ratemeter-scaler Model 2221

(Ludlum Measurements, Inc., Sweetwater, TX)

\section{C.1.2 Alpha Plus Beta}

Ludlum Gas Proportional Detector Model 43-68, Physical area: $126 \mathrm{~cm}^{2}$

(Ludlum Measurements, Inc., Sweetwater, TX)

Coupled to:

Ludlum Ratemeter-scaler Model 2221

(Ludlum Measurements, Inc., Sweetwater, TX)

Coupled to GeoXH Receiver and Data Logger

(Trimble Navigation Limited, Sunnyvale, CA)

Ludlum Geiger-Müller Probe Model 44-9, Physical area: $20 \mathrm{~cm}^{2}$

(Ludlum Measurements, Inc., Sweetwater, TX)

Coupled to:

Ludlum Ratemeter-scaler Model 2221

(Ludlum Measurements, Inc., Sweetwater, TX)

\section{C.2 LABORATORY ANALYTICAL INSTRUMENTATION}

High-Purity, Extended Range Intrinsic Detector

CANBERRA/Tennelec Model No: ERVDS30-25195

(Canberra, Meriden, CT)

Used in conjunction with:

Lead Shield Model G-11

(Nuclear Lead, Oak Ridge, TN) and

Multichannel Analyzer

Canberra's Apex Gamma Software

Dell Workstation

(Canberra, Meriden, CT) 
High-Purity, Extended Range Intrinsic Detector

Model No. GMX-45200-5

(AMETEK/ORTEC, Oak Ridge, TN)

used in conjunction with:

Lead Shield Model SPG-16-K8

(Nuclear Data)

Multichannel Analyzer

Canberra's Apex Gamma Software

Dell Workstation

(Canberra, Meriden, CT)

High-Purity Germanium Detector

Model GMX-30-P4, 30\% Eff.

(AMETEK/ORTEC, Oak Ridge, TN)

Used in conjunction with:

Lead Shield Model G-16

(Gamma Products, Palos Hills, IL) and

Multichannel Analyzer

Canberra's Apex Gamma Software

Dell Workstation

(Canberra, Meriden, CT)

Low-Background Gas Proportional Counter

Model LB-5100-W

(Tennelec/Caberra, Meriden, CT)

Tri-Carb Liquid Scintillation Analyzer

Model 3100

(Packard Instrument Co./Perkin Elmer, Shelton, CT) 
APPENDIX D

SURVEY AND ANALYTICAL PROCEDURES 


\section{D.1 PROJECT HEALTH AND SAFETY}

The proposed survey and sampling procedures were evaluated to ensure that any hazards inherent to the procedures themselves were addressed in current job hazard analyses. Prior to on-site activities, a pre-job integrated safety management checklist was completed and discussed with field personnel. Additionally, upon arrival at the site, contractor representatives provided the ORISE with general safety information within the project area. The planned activities were thoroughly discussed with site personnel prior to implementation to identify hazards present. ORISE also had a site escort at all times due to the various alarms and notifications associated with an active industrial facility. All survey and laboratory activities were conducted in accordance with Oak Ridge Associated Universities (ORAU) health and safety and radiation protection procedures (ORAU 2011b and c).

\section{D.2 CALIBRATION AND QUALITY ASSURANCE}

Calibration of all field and laboratory instrumentation was based on standards and sources traceable to National Institute of Standards and Technology (NIST).

Analytical and field survey activities were conducted in accordance with procedures from the following documents of the Independent Environmental Assessment and Verification (IEAV) Program:

- Survey Procedures Manual (ORISE 2008)

- Laboratory Procedures Manual (ORISE 2011b)

- Quality Program Manual (ORAU 2011a)

The procedures contained in these manuals were developed to meet the requirements of DOE Order 414.1C and the U.S. Nuclear Regulatory Commission (NRC) Quality Assurance Manual for the Office of Nuclear Material Safety and Safeguards and contain measures to assess processes during their performance.

Quality control procedures include the following:

- Daily instrument background and check-source measurements to confirm that equipment operation is within acceptable statistical fluctuations. 
- Participation in Mixed Analyte Performance Evaluation Program (MAPEP), NIST Radiochemistry Intercomparison Program (NRIP), and Intercomparison Testing Program (ITP) Laboratory Quality Assurance Programs.

- Training and certification of all individuals performing procedures.

- Periodic internal and external audits.

\section{D.3 SURVEY PROCEDURES}

\section{D.3.1 SURFACE SCANS}

Scans for elevated gamma radiation were performed by passing the detector slowly over the surface. The distance between the detector and surface was maintained at a minimum. Specific scan minimum detectable concentration (MDCs) for the NaI detector was not determined as the instrument was used solely as a qualitative means to identify elevated gamma radiation levels in excess of background. Identifications of elevated radiation levels that could exceed the site criteria were determined based on an increase in the audible signal from the indicating instrument.

Alpha plus beta scans were performed using small, hand-held gas proportional detectors with a $0.8 \mathrm{mg} / \mathrm{cm}^{-2}$ window. Identification of elevated radiation levels was based on increases in the audible signal from the indicating instrument. Beta surface scan MDCs were estimated using the approach described in NUREG-1507. The scan MDC is a function of many variables, including the background level. Additional parameters selected for the calculation of scan MDCs included a two-second observation interval, a specified level of performance at the first scanning stage of 95\% true positive and 25\% false positive rate, which yields a d' value of 2.32 (NUREG-1507, Table 6.1), and a surveyor efficiency of 0.5. The beta total efficiency was 0.11 for Co-60 (calibrated with Tc-99). The detector used had an ambient background of 370 counts per minute (cpm). The minimum detectable count rate (MDCR) and scan MDC was calculated as:

$$
\begin{aligned}
& \mathrm{B}_{\mathrm{i}}=(370)(2 \mathrm{~s})(1 \mathrm{~min} / 60 \mathrm{~s})=12 \text { counts } \\
& \mathrm{MDCR}=(2.32)(12 \mathrm{counts})^{1 / 2}[(60 \mathrm{~s} / \mathrm{min}) / 2 \mathrm{~s}]=241 \mathrm{cpm} \\
& \mathrm{MDCR}_{\text {surveyor }}=241 /(0.5)^{1 / 2}=340 \mathrm{cpm} \\
& \mathrm{Scan} \mathrm{MDC}=(508) /(.11)=3,100 \mathrm{dpm} / 100 \mathrm{~cm}^{2}
\end{aligned}
$$




\section{D.3.2 Surface ACtivity Measurements}

Measurements of total beta surface activity levels were performed using hand-held gas proportional detectors coupled to portable ratemeter-scalers. Count rates ( $\mathrm{cpm}$ ), which were integrated over one minute with the detector held in a static position, were converted to activity levels $\left(\mathrm{dpm} / 100 \mathrm{~cm}^{-2}\right)$ by dividing the count rate by the total static efficiency $\left(\varepsilon_{\mathrm{i}} \times \varepsilon_{\mathrm{s}}\right)$ and correcting for the physical area of the detector. ORISE did not determine construction material-specific background for each surface type encountered for determining net count rates. Instead, ORISE took the conservative approach followed by the licensee and subtracted instrument background $(370 \mathrm{cpm})$ when determining surface activity. The a priori MDC for beta activity is given by:

$$
M D C=\frac{3+(4.65 \sqrt{B})}{G \varepsilon_{t o t}}
$$

Where:

$$
\begin{aligned}
& \mathrm{B}=\text { background } \\
& \varepsilon_{\mathrm{tot}}=\text { total efficiency } \\
& \mathrm{G}=\text { geometry correction factor }(1.26)
\end{aligned}
$$

The a priori beta static MDC was approximately $670 \mathrm{dpm} / 100 \mathrm{~cm}^{2}$ for Co- 60 .

\section{D.3.2 Removable ACtivity Measurements}

Removable gross alpha and gross beta activity levels were determined using numbered filter paper disks, $47 \mathrm{~mm}$ in diameter. Moderate pressure was applied to the smear and approximately $100 \mathrm{~cm}^{2}$ of the surface was wiped. Smears were placed in labeled envelops with the location and other pertinent information recorded.

For tritium and C-14 determinations, a second smear was moistened with deionized water and an adjacent $100 \mathrm{~cm}^{2}$ was wiped. The smear was then sealed in a labeled liquid scintillation vial with the location and pertinent information recorded.

\section{D.3.2 SoIL SAMPLING}

Approximately 0.5 kilogram of soil was collected at the one sample location. The sample was placed in a plastic bag, sealed, and labeled in accordance with ORISE survey procedures. 


\section{D.4 RADIOLOGICAL ANALYSIS}

\section{D.4.1 GAMMA SPECTROSCOPY}

Samples were dried, mixed, crushed, and/or homogenized as necessary, and a portion sealed in a 0.5-liter Marinelli beaker or other appropriate container. The quantity placed in the beaker was chosen to reproduce the calibrated counting geometry. Net material weights were determined and the samples counted using intrinsic germanium detectors coupled to a pulse height analyzer system. Background and Compton stripping, peak search, peak identification, and concentration calculations were performed using the computer capabilities inherent in the analyzer system. All total absorption peaks (TAP) associated with the ROCs were reviewed for consistency of activity. TAPs used for determining the activities of ROCs and the typical associated MDCs for a one-hour count time were:

\begin{tabular}{|c|c|c|}
\hline \multicolumn{3}{|c|}{ Table D-1. MDC Derived from Total } \\
Absorption Peak \\
\hline Radionuclide & TAP (MeV) & MDC (pCi/g) \\
\hline Eu-152 & 0.344 & 0.11 \\
\hline Eu-154 & 0.723 & 0.13 \\
\hline Co-60 & 0.661 & 0.05 \\
\hline Cs-137 & 1.173 & 0.05 \\
\hline
\end{tabular}

Spectra were also reviewed for other identifiable TAPs.

\section{D.4.2 Gross APHA/Gross BetA ANALYsis}

Smears were counted on a low-background gas proportional system for gross alpha and beta activity. The minimum detectable concentration (MDC) of the procedure were $11 \mathrm{dpm}($ per $100 \mathrm{~cm}-1)$ and $14 \mathrm{dpm}$ for alpha and beta, respectively.

\section{D.4.3 H-3/C-14 SMEAR ANALYSIS}

Analyses for H-3 and C-14 smears were performed by placing the smear into scintillation cocktail and counting on a liquid scintillation analyzer. Samples were then spiked with a known amount of the appropriate standard and recounted. The typical MDC of the procedures are approximately 17 pCi/sample for H-3 and 8 pCi/sample for C-14. 


\section{D.4.4 H-3 IN SOIL AND CONCRETE SAMPLES}

Soil and concrete samples were combusted using a biological material oxidizer (BMO) system. The water vapor was trapped in an organic compound containing scintillation cocktail and counted for 60 minutes on a liquid scintillation analyzer. A matrix spike was run with each batch to determine chemical recovery. Typical MDC of this procedure is $2 \mathrm{pCi} / \mathrm{g}$.

\section{D.4.5 C-14 IN SOIL}

Samples were combusted using a biological material oxidizer (BMO) system. The carbon in the samples was converted to carbon dioxide and was carried through the system with an inert gas. The carbon dioxide was trapped in an organic compound containing scintillation cocktail and counted for 60 minutes in a liquid scintillation analyzer. A matrix spike was run with each batch to determine chemical recovery. The typical MDC of the procedure is $1.3 \mathrm{pCi} / \mathrm{g}$.

\section{D.4.6 NI-63 IN SoIL}

Iron was removed from the soil prior to nickel separation using anion exchange chromatography. Samples that contain sufficient amounts of radioactive cobalt are process through an anion exchange process prior to passing the samples through the Ni Resin. Other potential interfering elements are removed from the Ni column with a buffered ammonium citrate solution. Nickel is eluted off the column with dilute nitric acid. The Ni-63 activity is determined via liquid scintillation counting. A batch yield is used to determine chemical recovery. The typical MDC of this procedure is $2 \mathrm{pCi} / \mathrm{g}$.

\section{D.4.7 Detection Limits}

Detection limits, referred to as minimum detectable concentrations (MDCs), were based on 95\% confidence level via NUREG-1507 method. Because of variations in background levels, measurement efficiencies, and contributions from other radionuclides in samples, the detection limits differ from sample to sample and instrument to instrument. 